\title{
Maintenance of genetic differentiation across a transition zone in the sea: discordance between nuclear and cytoplasmic markers
}

\author{
C. Lemaire, J.-J. Versini and F. Bonhomme*
}

Laboratoire Génome, Populations, Interactions, Adaptation, UMR 5171 CNRS-IFREMER-Université Montpellier II, Station Méditerranéenne de I'Environnement Littoral, 1 Quai de la daurade, 34200 Sète, France.

*: Corresponding author : Tel.: (+33) 4674633 72; fax: (+33) 4674633 99; bonhomme@univ-montp2.fr

\begin{abstract}
:
To investigate the origin and maintenance of the genetic discontinuity between Atlantic and Mediterranean populations of the common sea bass (Dicentrarchus labrax) we analysed the genetic variation at a fragment of mitochondrial cytochrome $b$ sequence for 18 population samples. The result were also compared with new or previously published microsatellite data. Seven mitochondrial haplotypes and an average nucleotidic divergence of 0.02 between Atlantic and Mediterranean populations that matches a Pleistocene allopatric isolation were found. The frequency variation at the cytochrome b locus was many times greater between Atlantic and Mediterranean populations ( $=0.67)$ than at microsatellite loci (

$=0.02$ ). The examination of the different evolutionary forces at play suggests that a sex-biased hybrid breakdown is a likely explanation for part of the observed discrepancy between mitochondrial and nuclear loci. In addition, an analysis is made of the correlation between microsatellite loci points towards the possible existence of a hybrid zone in samples from the Alboran Sea.
\end{abstract}

Keywords: genetic-transitions; microsatellites-; mtDNA-; phylogeography-; reproductive-isolation 


\section{INTRODUCTION}

Understanding the origin and maintenance of genetic discontinuities remains a central point in evolutionary biology which is exemplified by recent publications which examine the classical dilemma of allopatric vs. sympatric speciation (Orr and Smith 1998; Dieckmann and Doebeli 1999; Kirkpatrick 2000; Schluter 2001; Via 2001). The question is especially relevant in the sea, where efficient physical barriers are difficult to find (Avise 1994; Palumbi 1994, 1996). Basic information enabling us to identify genetic discontinuities is far less abundant for marine species than for terrestrial ones (see for example Avise 1994, 1998, 2000; Bermingham et al. 1997; Bowen and Grant 1997; Lessios et al. 1998; Arnaud et al. 2000; Lee 2000; Muss et al. 2001; Perrin and Borsa 2001; Planes and Fauvelot 2002). Regardless of the possible existence of sympatric or nearly sympatric (microallopatric) cases of genetic divergence (Duffy, 1996; Mokady and Brickner 2001; Carlon and Budd 2002 ; Rundle and Schluter 2002), it has been established that actual or ancient physical barriers have also played an important role in promoting reproductive isolation in the marine environment, leading in some instances to allopatric speciation (see Knowlton et al. 1993 for the Panama isthmus).

Among the mechanisms frequently invoked for forming barriers, it is common knowledge that Pleistocene glacial episodes have been characterised by cyclical variation of sea level and surface temperatures which have significantly influenced the physical connection between water masses and their inhabiting species. This is true around the Gibraltar strait where cold episodes are thought to have restricted populations of temperate species further south along the African coast in the Atlantic Ocean or further south-east in the Mediterranean Sea off the coasts of Libya and Egypt. Thus, many species ranging on each side of the Gibraltar strait are expected to have experienced this process of cyclical fragmentation followed by genetic differentiation (see for instance Borsa et al., 1997). It is 
unclear whether evidence of these processes remains, or whether their effects vanish at each interglacial warm episode because of subsequent gene flow.

The common (or European) sea bass (Dicentrarchus labrax L. (1758), Teleost; Perciformes, Moronidae) is one example where such evidence is still detectable. This fish ranges in coastal waters of the Atlantic Ocean from Scandinavia to Western Sahara and in the whole Mediterranean Sea, and previous genetic works based on allozymes and mitochondrial markers have led to the identification of three genetically distinct zones : the north-eastern Atlantic Ocean, the western Mediterranean and the eastern Mediterranean (Benharrat et al., 1983; Patarnello et al., 1993; Allegrucci et al., 1997; Caccone et al., 1997; Cesaroni et al., 1997). On the basis of the six microsatellite loci, the transition zones have been localised between the Atlantic (plus the Alboran Sea) and the western Mediterranean, at the AlmeriaOran oceanic front (Naciri et al., 1999), and between eastern and western Mediterranean somewhere around the Siculo-Tunisian strait (Bahri-Sfar et al., 2000).

In this paper, we focus on the study of the former transition zone. Understanding the maintenance of transition zones is particularly relevant in the context of discussing speciation mechanisms occurring in the sea, as D. labrax has great dispersal potentialities including a planktonic larval phase of two to three months (Pickett and Pawson 1994) and a migratory behaviour of adults (Barnabé, 1980; Pickett and Pawson, 1994), both which could lead displacements over several hundreds of kilometres (Pickett and Pawson, 1994). Despite these features, a clear transition appears to occur in the eastern part of the Alboran Sea (Naciri et al., 1999). The equilibrium gene flow $\left(N_{e} m\right)$ between the two basins has been estimated from a highly significant $F_{S T}(\hat{\theta}=2.23 \%)$ to be the result of approximately only 11 effective migrants per generation (Naciri et al. 1999), whereas the same study also revealed fairly homogeneous populations on either side $(\hat{\theta}=0.010, p<0.001$ in the Atlantic and $\hat{\theta}=0.002$, $p>0.05$ in western Mediterranean). These results support the hypothesis that the physical 
barrier has not been sufficient to prevent gene flow between Atlantic and Mediterranean individuals. Thus while a physical barrier may well be the source of this genetic discontinuity, a genetically determined barrier is invoked to explain its persistence.

A genetic barrier may result from a multitude of mechanisms, including post-zygotic isolation such as hybrid breakdown (endogenous factors) or disruptive environmental selection (exogenous factors), pre-zygotic isolation mechanisms such as philopatry (Fitzsimmons et al. 1997; Buonaccorsi et al. 1999, but see also Buonaccorsi et al. 2001 for criticisms), assortative mating/sexual selection (Hull, 1998; Nagel and Schluter, 1998) or habitat choice (Behegaray and Levy, 2000; Schmidt et al., 2000; Rocha et al., 2002, Bierne et al. 2002). These mechanisms may all contribute to speciation (Kirkpatrick and Ravigné 2002). In the presence of local adaptations, parapatric speciation can occur between adjacent populations if such behavioural processes and genetic drift are sufficiently strong to counteract the homogenising effects of gene flow (see for instance Gavrilets et al., 2000 for theoretical developments), and thus the effective dispersal behaviour of individuals is a key parameter.

While the whole genome should roughly be equally affected by a physical barrier, genomic heterogeneity may arise in semi-permeable genetic barriers to gene flow because of the occurrence of selective pressures (Barton Hewitt 1985, 1989; Harisson 1990; Rieseberg et al. 1999). As the mitochondrial genome is not physically linked to the nuclear one it may exhibit different dynamics, crossing the genetic barriers more rapidly, being influenced by sex-biased isolation mechanisms (e.g. sex-biased hybrid breakdown or even philopatry), or it may itself be involved in some kind of reproductive isolation (Clark and Lyckegaard 1988; Burton et al. 1999). It has thus been important to compare the mitochondrial genome dynamics with those of the nuclear genome (Harisson 1990). The present paper shows that the comparison between nuclear microsatellites and mitochondrial DNA data in D. labrax is also 
relevant, as it not only corroborates the presence of a genetic barrier but sheds some light on its maintenance, strongly suggesting the existence of sex-biased reproductive isolation mechanisms.

\section{MATERIALS AND METHODS}

\section{Sampling}

Eighteen samples were chosen around the Almeria-Oran front: 7 samples were located in Atlantic Ocean, 3 in Alboran Sea and 8 in western Mediterranean. Ten samples were similar between this study and that of Naciri et al. (1999), 3 to that of Bahri-Sfar et al. (2000), 2 to that of García de León et al. (1997) and 1 to that of Lemaire et al. (2000). The two remaining samples (FYEU and EMAM) were specific to this study. Samples size was $33 \pm$ 6.35 with a maximum of 63 and a minimum of 9 individuals (Fig. 1; Table 1).

\section{Molecular analyses}

The eighteen samples have been analysed using a $304 \mathrm{bp}$ fragment of the mitochondrial cytochrome $b$ gene. Specific primers $\left(\mathrm{CBF} 1: 5^{\prime}-\right.$ CGGTTCGCTCTTAGGCCTATGC-3' and CBR1 : 5'GGGCAACACATAGCCTACGAAGGC-3') were designed for Dicentrarchus labrax from the sequence of cytochrome $b$ available in Genbank (accession number : AF143189). DNA amplifications were performed by polymerase chain reaction (PCR) in microtiter plates, with each reaction containing $3 \mu 1$ DNA solution (10-20ng), $10 \mathrm{pmol}$ of each primer, $0.2 \mathrm{mM}$ each dNTP, $2.5 \mathrm{mM} \mathrm{MgCl}_{2}$, $1 \mathrm{X}$ polymerase buffer and $0.5 \mathrm{U}$ Taq polymerase ( $25 \mu 1$ final volume). Each well was overlaid with $20 \mu 1$ mineral oil, and PCR was carried out in a Crocodile III thermocycler. Discrimination of haplotypes was performed by Single Strand Conformation Polymorphism (SSCP; Orita et al. 1989) on a vertical non-denaturing 12\% acrylamide gel 
(ratio acryl : bisacryl 37:1; BDH, Poole, England) with 1X TBE buffer. DNA bands were visualized by ethidium bromide staining under a UV transilluminator.

Additionally, genotypes at six microsatellite loci (García de León et al. 1995) were available for most of the samples (García de León et al., 1997; Naciri et al., 1999; Bahri-Sfar et al., 2000). These data were generated for two new samples, FYEU (Yeu Island, Gulf of Biscay) and EMAM (lagoon of Mar Menor, Western Mediterranean) according to the protocol described in Naciri et al. (1999).

\section{DNA sequencing}

For each mtDNA haplotype identified, the 304 bp PCR products were sequenced directly for two individuals per haplotype by the method of Sanger et al. (1977) using primer CBF1 dye-labelled with fluorescing CY5. Sequences were performed with the "Thermo Sequenase Fluorescent Primer Cycle Sequencing" kit with 7-deaza-dGTP" (USB Corporation, Cleveland, USA) and analysed with the automatic A. L. F. DNA Sequencer (Pharmacia, Biotech, Uppsala, Sweden).

\section{Sequence alignment}

All the sequences were automatically aligned and manually corrected with the alignment interface of the automatic sequencer : Alfwin Sequence Analyser Module v2. 10. 06, 1998, (Amersham Pharmacia Biotech, Uppsala, Sweden). Alignment with already published sequences as those of Allegrucci et al. (1999) were manually performed with the BioEdit software (Hall, 1999). 


\section{Statistical analyses}

Allele and haplotype frequencies as well as population genetic parameters were estimated with the GENETIX v4.02 software (Belkhir et al., 1996-2002). Gene and haplotype diversity $\left(\mathrm{He}_{n b}, \mathrm{Nei}, 1987\right)$ were estimated respectively on microsatellite and cytochrome $b$ data for each sample with correction for haplotype data $[(2 N-1) /(2 N-2) ; N=$ sample size $]$. Confidence intervals for gene diversities were estimated among samples of each basin (Mediterranean and Atlantic/Alboran). Wright's fixation indices $F_{I S}$ and $F_{S T}$ were estimated respectively by Weir and Cockerham (1984: $\hat{f}$ and $\hat{\theta}$ ). Estimates of $f$ were only computed on microsatellite data. All tests ( $f$ or $\theta=0)$ were performed by permutation of alleles or individuals respectively. $\hat{\theta}_{C}$ and $\hat{\theta}_{N}$ will be used to denote cytoplasmic (mitochondrial) and nuclear (microsatellites) $\hat{\theta}$ estimates respectively. The sequential Bonferroni method (Rice, 1989) was used for multiple tests. All distance trees were inferred from Reynolds et al.'s (1983) coancestry genetic distance $(\mathrm{D}=1-\ln (1-\theta))$ matrix by the NEIGHBOR procedure of the phylogenetic package PHYLIP 3.2 (Felsenstein, 1993).

For each sample, nucleotidic diversities $\pi$ (Tajima, 1983; Nei, 1987) were estimated for mitochondrial haplotypic data. Phylogenetic relations between sea bass mitochondrial haplotypes were also investigated. The average transition/transversion ratio among pairwise comparisons of sequences and nucleotidic distances were estimated using the Kimura 2parameters model (Kimura, 1980) implemented in the MEGA 2.1 software (Kumar et al. 2001). The different D. labrax haplotypes were compared with a sequence of the congeneric species Dicentrarchus punctatus, the spotted sea bass (Genbank accession number : AF240740). A network of phylogenetic relationships between haplotypes was reconstructed by the split decomposition (Bandelt and Dress, 1992) method implemented in SPLITS TREE 3.2 
(Huson, 1998; see also Posada and Crandall, 2001 for comments about network reconstructions).

Joint estimations of gene flow and divergence time on cytochrome $b$ between the Atlantic-Alboran and the Mediterranean groups were carried out with the Bayesian inference method of Nielsen and Wakeley (2001) implemented in the program MDIV. Using a Markov Chain Monte Carlo simulation of the coalescence process, this program obtain posterior estimates of the classical parameters of diversity $\left(\theta=2 N_{e f} \mu\right)$, migration $\left(\mathrm{M}=2 N_{e f} m\right)$ and divergence time between the two populations ( $\mathrm{T}=\mathrm{t} / 2 N_{e}$ ) with $N_{e f}$ being the female haploid effective size, $\mu$ the mutation rate, $m$ the female migration rate and $t$ the number of generations. Initially, the method was tested for different values of $\mathrm{M}(0 ; 2$ and 5$)$ and $\mathrm{T}(0 ; 5$ and 10). After this first step, both parameters were adjusted $(\mathrm{M}=5$ and $\mathrm{T}=10)$ and the process was repeated five times with a different seed number for checking the stability of estimates. For each replicate the settings of the Markov Chain were fixed at 5 million steps and a burning time of 1 million steps.

We have also performed a neutrality test using molecular variation on the cytochrome $b$ gene. The Tajima's neutrality test (Tajima, 1989) is based on haplotype sequence information and compares two estimators of $\theta\left(2 N_{e f} \mu\right.$; $N_{e f}$ being the female haploid effective size and $\mu$ the mutation rate) under an infinite-site model without recombination which is appropriate for mitochondrial genome. It detects an eventual departure from mutation-drift equilibrium which could be caused either by selection or changes in effective size like bottlenecks. This test was carried out on the haplotypes of cytochrome $b$ using the ARLEQUIN software (Schneider et al., 2000). 
RESULTS

Gene and haplotype diversities

The analyses of the 304 bp fragment of cytochrome $b$ by SSCP on 594 individuals revealed seven haplotypes named A, B, C ,D, E, F and G. This result was confirmed by sequencing of two individuals sharing each haplotype. We did not find heteroplasmy in any individual, a result concordant with the data of Patarnello et al. (1993) on the cytochrome $b$ and contrary to Cesaroni et al. (1997) on the D-loop (Table 2). Cytochrome $b$ data gave haplotype diversities ranging from 0.00 (FSET, one haplotype fixed) to 0.69 (MNAD). At the nuclear loci, estimates of multilocus $\mathrm{He}_{n b}$ ranged from 0.84 (TGOU and TISK) to 0.91 (PAVR; Table 3). As previously observed by Naciri et al. (1999), gene diversities of the samples from Atlantic-Alboran region $\left(H e_{n b}=0.90 \pm 0.006\right)$ were significantly greater than those of Mediterranean $\left(\mathrm{He}_{n b}=0.86 \pm 0.008\right.$; Mann-Whitney U-test, $\left.\mathrm{p}<0.0001\right)$. This difference was confirmed at the mitochondrial level where haplotypic diversities were four times greater in Atlantic and Alboran $\left(\mathrm{He}_{n b}=0.42 \pm 0.105\right)$ than in Mediterranean samples $\left(\mathrm{He}_{n b}=0.10 \pm 0.066\right.$; Mann-Whitney U-test, $\mathrm{p}<0.0001)$. Furthermore, estimates of average nucleotidic diversity $\pi$ were almost tenfold greater in Atlantic-Alboran samples $\left(0.00550 \pm 1.0 .10^{-3}\right)$ than in Mediterranean ones $\left(0.00067 \pm 6.0 .10^{-4}\right.$; Mann-Whitney U-test, $\left.\mathrm{p}<0.0001\right)$.

Because of the presence of null alleles at the locus Labrax-6 (see García de León et al., 1997), estimates of multilocus $f$ are given with and without this locus. The two new samples EMAM and FYEU do not demonstrate significant departures from Hardy-Weinberg equilibrium. Exclusion of the locus Labrax-6, Western Mediterranean samples seemed to be close to panmixia ( $\hat{f}=0.005, p>0.05$ ) while this was not the case for the Atlantic-Alboran samples ( $\hat{f}=0.039, p<0.001$ ), which has already been noted by Naciri et al. (1999). 


\section{Population differentiation}

Figure 2 describes the variation of cytochrome $b$ haplotype frequencies for different samples which was characterised by a replacement of the main haplotype (A) in Atlantic samples by the haplotype B in Mediterranean samples. The latter samples were characterised by only two haplotypes (B and E), except in AGLA and TBIZ samples where haplotype A is also observed. The subsequent global $\hat{\theta}_{C}$ is $0.53(p<0.001)$. Table 4 gave the matrix of pairwise estimates of $\theta$ for both mtDNA and microsatellite data. The new sample of Mar Menor (EMAM), close to the Almeria-Oran front was significantly differentiated from all other samples at nuclear loci ( $\hat{\theta}_{N}=0.023, p<0.001$ against Mediterranean samples and $\hat{\theta}_{N}=0.021, p<0.001$ against samples from Atlantic-Alboran) whereas it was genetically similar to Mediterranean samples at the cytochrome $b$ locus but still different from AtlanticAlboran's samples $\left(\hat{\theta}_{C}=0.613, p<0.001\right)$. The tree in Figure 3 inferred from microsatellite data illustrates the fact that the newly analysed Mar Menor (EMAM) sample occured in between the Mediterranean and Atlantic clades, despite a bootstrap value of only $77 \%$ with the former. The new sample (FYEU) was clearly assigned as Atlantic at both nuclear and cytoplasmic loci.

Genetic differentiation at the mitochondrial locus appeared to be several fold greater than that observed at microsatellite loci (see Table 4). Overall $\hat{\theta}$ estimate was more than twenty-fold greater at cytochrome $b\left(\hat{\theta}_{C}=0.53, p<0.001\right)$ than at microsatellite loci $\left(\hat{\theta}_{N}=0.02\right.$, $p<0.001)$. Intra-basin estimates were $\hat{\theta}_{C}=0.023(p>0.05) v s . \hat{\theta}_{N}=0.004(0.01<p<0.05)$ for western Mediterranean samples (excluding the sample Mar Menor), and $\hat{\theta}_{C}=0.061$ $(p<0.001)$ vs. $\hat{\theta}_{N}=0.008, p<0.001$ for Atlantic-Alboran samples. The most important difference between cytoplasmic and nuclear differentiation occurs at the inter-basin level 
(Mediterranean Sea without EMAM vs. Atlantic-Alboran) where $\hat{\theta}_{c}=0.676(p<0.001)$ was more than thirty-fold larger than $\hat{\theta}_{N}=0.023(p<0.001)$.

\section{Phylogeny of haplotypes}

Kimura-2-parameters distances (Kimura, 1980) have been estimated with a mean transition/tranversion rate of 2.6 (Table 5). These estimates ranged from 0.004 (B and E) and $0.039(\mathrm{C}$ and $\mathrm{F})$, corresponding to one and nine mutations steps respectively. The mean distance between $D$. labrax and $D$. punctatus was $0.133 \pm 0.006$. The split decomposition network of the Atlantic-Alboran and Mediterranean haplotypes demonstrated that, with the exception of haplotype $\mathrm{C}$ close to $\mathrm{E}$, the haplotypes clustered according to their main area of occurrence (Fig. 4).

Estimates of mitochondrial gene flow and time of divergence between individuals from the Atlantic-Alboran and the Mediterranean basins are also given by the MDIV program (Nielsen and Wakeley 2001). According to this method the global genetic diversity estimate was $\hat{\theta}=0.785$ and the migration rate estimate was $\hat{M}=0.384$, suggesting that on average one female is exchanged between the two basins every three generations. Estimates of T were more difficult to assess because the distribution of $\mathrm{T}$ reached a plateau at $\mathrm{T}=3.5$ and $\operatorname{did}$ not decrease for higher values (not shown). However, we could consider that the value of $\mathrm{T}=3.5$ might represented the minimum divergence time.

No departure from mutation/drift equilibrium has been observed except at the BANV sample (Tajima's $D=-2.39, p<0.01$; data not shown). Nevertheless after a Bonferroni correction for multiple tests (Rice 1989) the departure did not remain significant. 
DISCUSSION

In the present paper, we further documented the pattern of genetic differentiation across a transition zone for the marine teleost fish, Dicentrarchus labrax. Natural populations of the European sea bass have been the subject of many studies using several types of markers although few studies have focused on transition zones . Genetic variation at the mitochondrial cytochrome $b$ was analysed and compared to previous published data on microsatellite loci (Naciri et al., 1999). In the following we discuss the possible phylogeographic origin of $D$. labrax present-day populations, we explore the cause(s) of the strongly contrasted levels of mitochondrial and microsatellite $\hat{\theta}$ s observed at the inter-basin level, and finally we discuss of the implication of this finding in the maintenance of the genetic transition between Atlantic-Alboran and Mediterranean populations.

\section{Phylogeography of D. labrax}

The mitochondrial variation in sea bass is consistent with an ancient history. When looking at the network in Figure 4, it is apparent that the most frequent Mediterranean haplotype (B) and the most frequent Atlantic one (A) are distinct. The overall mean of Nei and Li's (1979) nucleotide divergence, which takes into account ancestral polymorphisms, between the Atlantic-Alboran and Mediterranean basins is $0.018 \pm 0.001$. This means a divergence of 0.9 to $3.6 \mathrm{My}$ according to a divergence rate of 2 to 0.5 percent per My (see Brown et al. 1979 for a standard reference in fish). The estimate of T given by MDIV (Nielsen and Wakeley 2001) implies a divergence beginning at least at $t=3.5 * 2 N_{e f}$. Considering a divergence rate ranging between 0.5 and $2 \%$ per My, the mutation rate per lineage is calculated as 0.25 to $1.10^{-8}$ mutations per nucleotide per year. Assuming a generation time of three years in the sea bass and a 304 bp long fragment, we expect a haplotype mutation rate 
between $\mu=0.25 \cdot 10^{-8} * 3 * 304 \approx 2.5 \cdot 10^{-6}$ and $10^{-5}$ mutations per generation for our cytochrome $b$ fragment. Thus, considering the estimate of $\theta=2 \mathrm{~N}_{\mathrm{ef}} \mu=0.785$ and the time of divergence in number of generation $t=\mathrm{T} * 2 \mathrm{Nef}$, the divergence time can be expressed as $t=\frac{\theta T}{\mu}$. Thus, the last divergence event may have occurred between 0.27 and $1.1 \mathrm{My}$. These divergence times are consistent with the hypothesis of the last isolation episode occurring during the Pleistocene glaciation cycles (1.8 to $0.01 \mathrm{My}$ ago). We should consider these results cautiously because the underlying model in MDIV assumes a constant effective size since divergence and equal effective sizes in the two populations. Nevertheless, Tajima's test does not detect any recent significant change in population effective sizes (for example a bottleneck followed by a demographic expansion) although the power we have to detect this by this test is limited given the low amount of nucleotide polymorphism in each population.

Finally, the rooting of the network by the outgroup $D$. punctatus suggests that the common Mediterranean haplotypes derive from a larger Atlantic coalescent, which seems more diversified. This fits well with the observed increased haplotypic and nucleotidic diversities for mtDNA and expected heterozygosity for microsatellites we found for the Atlantic samples. This, together with the lack of reciprocal monophyly, points towards a probable Atlantic origin of Mediterranean see bass rather than the contrary, although this last possibility cannot be excluded, especially in the case where the effective sizes are very different. Nevertheless, the presence of haplotypes B and C in the Atlantic and A in the Mediterranean suggests that rare exchanges may occur from time to time. Assuming a simple model of divergence, with the possible occurrence of migration between two populations (Nielsen and Wakeley 2001) we obtained an estimate of $\mathrm{M}=0.385$ (one successful female every three generations). It is nevertheless very difficult to unambiguously prove that mtDNA flow still occurs across the barrier. However, the frequency gradient observed within the 
Atlantic (Fig. 2) seems to be compatible with an introgression queue which would have been homogenised if gene flow had stopped for long.

\section{Reduction of inter-basins gene flow}

The estimate of genetic differentiation observed at microsatellite loci is the same as that reported by Naciri et al. (1999). This $\hat{\theta}_{\mathrm{N}}$ estimate could correspond to a number of effective migrants per generation of about 11 for a $\mathrm{Ne}$ of $10^{4}$ and a migration rate $\mathrm{m}$ of $10^{-3}$. However, taking into account the important dispersal potential of D. labrax (Pickett and Pawson, 1994), this estimate of realised gene flow appears to be quite low.

Several hypotheses could be proposed to explain the persistence of the observed genetic differentiation. The equilibrium between migration and drift may not have been reached since the last contact event. In this case, despite a currently greater gene flow, the genetic differentiation may be overestimated because of incomplete re-homogenisation. However, if we suppose that the contact between the two differentiated populations occurred at the end of the last glaciation (ca. 15000 years ago) and a generation time of two to three years, 5000 to 7500 generations may have occurred up until now. In a simple model with migration and drift, Slatkin (1985) has shown that equilibrium is reached in about $\mathrm{t}=1 / \mathrm{m}$ generations. Assuming a migration rate $m \approx 10^{-3}$ as given above, the time required for reaching equilibrium would be around $t=10^{3}$ generations. Thus the apparent migration rate $\left(m=10^{-3}\right)$ and the time elapsed since the last glaciation (>5000 generations) are compatible with an equilibrium situation. A non equilibrium state since the presumed time of secondary contact would imply a lower migration rate. We can thus consider that, equilibrium reached or not, the effective gene flow between the Atlantic and Mediterranean basins is reduced (a few successful individuals per generations). 
A possible explanation for this reduced gene flow would be that the Almeria-Oran front, where incoming Atlantic waters meet resident Mediterranean layers, may constitute a physical barrier for migration. If this is eventually plausible at the larval stage, this certainly is not the case for juveniles and adults that are excellent swimmers able to withstand large salinity and temperature changes (Barnabé, 1980; Pickett and Pawson, 1994) even if certain genotypes seems to be more adapted than others to salinity changes in Mediterranean (Allegrucci et al., 1994; 1997; Lemaire et al., 2000). Moreover, although genetic discontinuity between Atlantic and Mediterranean populations has been reported for some species (see for instance Daguin et al., 1999; Garcia-Martinez et al. 1999; Lundy et al. 1999), genetic homogeneity has nonetheless been observed on each side of the water front in species with similar or even less pronounced dispersal abilities (Borsa et al. 1994, Blanquer et al. 1992, De Metrio 1995). Hydrological factors alone are therefore unable to explain the persistence of the observed genetic disjunction. We should therefore consider the presence of a genetically determined barrier resulting from population vicariance in conjunction with a physical barrier, both of which are expected to coincide (Barton 1979). There are some good examples in the marine literature where the problem of the possible co-occurrence of a physical and a genetic barrier is addressed, including Point Conception in California (review in Burton 1998) and Cap Canaveral in Florida (review in Briggs 1974; Avise 1992; Cunningham and Collins 1994). In both cases, although currents are thought to reduce dispersal, they seem to be insufficient by themselves to explain the differentiation observed for certain species while genetic homogeneity can be found in the same area for other species with similar dispersal abilities. 


\section{Comparisons of differentiation levels between nuclear and cytoplasmic loci}

The inter basin $\theta_{C}$ estimate at mitochondrial cytochrome $b$ is more than thirty times greater than the $\theta_{N}$ estimated at the six nuclear microsatellite loci. Let $N_{e}$ and $N_{e f}$ be the total and female effective sizes respectively and $m$ and $m_{f}$ the total and the female migration rate respectively. In populations with balanced sex-ratio at mutation-drift equilibrium, and because of haploidy (vs. diploidy) and maternal (vs biparental) inheritance, the estimate of $\theta$ at a cytoplasmic locus is expected to be about fourfold larger than at a nuclear one:

With the expressions of $\hat{\theta}$ being $\hat{\theta}_{N}=\frac{1}{1+4 N_{e} m}$ for a nuclear locus and $\hat{\theta}_{C}=\frac{1}{1+2 N_{\text {ef }} m_{f}}$ for cytoplasmic locus with maternal inheritance, the upper limit of the ratio $\frac{\hat{\theta}_{C}}{\hat{\theta}_{N}}=\frac{1+4 N_{e} m}{1+2 N_{e f} m_{f}}$ can not exceed 4 when $N_{e m}>>1$ in the absence of biased sex ratio $\left(N_{e f}=\right.$ $\left.N_{e} / 2\right)$ and no sex biased migration rate $\left(m_{f}=m\right)$.

Thus, the expectations for measure of gene flow can also be deduced from these relations as following:

$N_{e} m=\frac{1}{4}\left(\frac{1}{\hat{\theta}_{N}}-1\right)$ at a nuclear locus and $N_{e f} m=\frac{1}{2}\left(\frac{1}{\hat{\theta}_{C}}-1\right)$ (see Fitzsimmons et al., 1997a) for a mitochondrial locus.

Thus, with respect to the above-mentioned conditions, the nuclear gene flow is expected to be at most twice as large as the mitochondrial one. Any departure from these conditions could lead to another ratio between nuclear and mitochondrial $\theta$ s and gene flow estimates. For example, a sex ratio bias in favour of males would lead to a reduced female effective size and therefore an increased sensitivity to drift effect that implies a higher $\hat{\theta}_{c}$. Sex related migration rate may also introduce a strong bias in the comparison between 
cytoplasmic and nuclear genetic variation. A female effective migration smaller than the male one would directly increase $\hat{\theta}_{C}$.

In the following we discuss the possible contribution of drift, mutation, migration and finally reproductive isolation in relation to the strong discrepancy observed between genetic variation at nuclear and mitochondrial loci.

\section{Drift}

First, the twenty five-fold difference observed here could be due to a reduced effective population size in females caused by a male biased sex ratio. In fact, a reduced female effective population size, which would increase drift effects and decrease the female gene flow, could lead to a much larger estimate of $\theta$ at a mitochondrial locus. A comparative study of mitochondrial and nuclear genetic variation may reveal a bias in sex ratio. Such a bias has been observed in reared stocks of sea bass (Bruslé and Roblin 1984; Blasquez et al. 1995) with an average of $80 \%$ of males. Observations in natural samples are discordant since there is evidence of both male (García de León 1995) and female biased sex ratios (Arias 1980). The condition of a ratio of 4 between nuclear and mitochondrial $\hat{\theta}$ s seems to be fulfilled at the intra-basin level (2.71 for Mediterranean and 4.11 for Atlantic/Alboran) but not for interbasin comparisons (37.65). If differences in $\theta$ estimates between cytoplasmic and nuclear markers were due to biases in sex ratio, we should observe the same differences at intra and inter basin levels. Thus male biased sex ratio, if it does exist, cannot in itself explain the observed differences of genetic variation between loci.

\section{Mutation}

Differences in mutation rate between class of markers could be invoked to explain the differences in level of genetic variation. On one hand, mitochondrial DNA of vertebrates is reputed to evolve rapidly (see for review Avise, 1994; Gerber et al., 2001; Rand, 2001) and 
could lead to elevated diversity and high divergence between isolated populations.

Microsatellite loci are also known to evolve at high mutation rates (see for instance, Jarne and Lagoda 1996; Slatkin 1995), a feature which is often associated with homoplasy (Estoup et al. 1995; Garza and Freimer 1996; Viard et al. 1998) and which could mimic gene flow and decrease the estimation of genetic differentiation. Is size homoplasy on microsatellite responsible of the observed differences in $\hat{\theta}$ ? In a recent study, Estoup et al. (2002) have shown that homoplasy occurring at microsatellite loci rarely affects the estimation of $\theta$, especially when migration is prominent in face to mutation. A study on the flat oyster (Ostrea edulis) (Launey et al., 2002) reaches the same conclusions about the level of genetic differentiation between microsatellites and allozymes.

Another explanation would be that estimate of $\theta$ at highly variable loci like microsatellites would asymptotically approach a value inversely proportional to the amount of polymorphism present at intra-population levels (Hedrick, 1999). Thus, the small amount of inter-population variation at microsatellites could be explained by the high intra-populational gene diversities compared to the ones observed at cytochrome $b$. However, the genetic variation of microsatellite loci in sea bass is far from the limit as shown by the two following examples. First, the genetic variation in the congeneric species Dicentrarchus punctatus is five time larger than in D. labrax at the same microsatellite loci, despite a greater number of alleles (Bonhomme et al., 2002). Secondly, in the study of Benharrat et al. (1983), 19 allozymic loci were analysed on four (three Mediterranean and one Atlantic) samples. Enzymatic markers are assumed to mutate less than both mitochondrial (Avise, 1994) and microsatellite loci. When an unbiased sex ratio, no sex biased migration rate and neutrality for each markers are assumed, the level of differentiation at allozymes is at most fourfold smaller than at cytochrome $b$ (i.e. $0.67 / 4=0.167$ ). We have estimated the $\theta$ parameter (Weir and Cockerham, 1984) from genotype frequencies reported in the study of Benharrat et al. (1983). 
The inter-basin differentiation reaches $\hat{\theta}_{\text {Atl-Med }}=0.263(p<0.001)$ when all loci are considered. However, one locus $(M e-1)$ strongly differentiates the two basins $\left(\hat{\theta}_{\text {Att-Med }}=\right.$ $0.594, p<0.001)$ and may not be neutral considering its implication in selective processes in Mediterranean (Allegrucci et al., 1994, 1997; Lemaire et al., 2000). After removing this locus, $\hat{\theta}_{\text {Atl-Med }}$ decreases to $0.077(p<0.001)$, and is of the same order of magnitude as microsatellites $\left(\hat{\theta}_{\text {Att-Med }}=0.025, p<0.001\right)$ and far from what was expected if it was a quarter of the mitochondrial value (0.167).

We can thus conclude that differences in mutation rate are not likely to explain the discrepancy between nuclear and cytoplasmic markers.

\section{Migration}

Sex biased migration rates have been deduced from comparison of cytoplasmic and nuclear markers in many terrestrial and freshwater macaque monkeys (cercopithecinae; Melnick and Hoelzer 1992), oilbirds (steatornithidae; Guttiriez 1994), broad white fish (salmonidae; Patton et al. 1997), kokanees (salmonidae; Taylor et al. 1997) and various marine organisms (marine green turtles, Fitzsimmons et al., 1997a, b; humpback whales, Palumbi and Baker 1994; sperm whales, Lyrholm et al. 1999). One more time, if differences in $\theta$ estimates between cytoplasmic and nuclear markers were due to a systematic sex-biased migration, we should observe the same differences at intra and inter basins level.

\section{Reproductive isolation mechanisms}

Finally, to explain a far more pronounced reduction in mtDNA compared to nuclear gene flow between the two basins than within each basin, sex-biased reproductive isolation or 
direct selection acting on mtDNA may be invoked. Although selection is known to occur on mtDNA (see for review Gerber et al. 2001; Rand et al. 2001), a direct involvement of mtDNA in the barrier, in the form of disruptive exogenous natural selection, seems unlikely. On the other hand, accumulating evidence suggests that the mitochondrial genome is involved in epistatic relation with nuclear genes and that it could adapt to differentiated nuclear backgrounds (Clark and Lyckegaard 1988; Gerber et al. 2001; Rand et al. 2001). A second possibility lies with the maternal inheritance, as female-biased hybrid breakdown may account for the results obtained. One can hypothesise that female hybrids between Atlantic and Mediterranean individuals could be counter-selected, or that hybrid individuals differentiate much less often into females than males (a large part of sex-determinism in sea bass seems to be eco-phenotypic, with a quite long undetermined period of six months (Saillant et al. 2002; 2003)). Female gene flow would thus be restricted as observed in our data. Sex-biased migration behaviour may also have differentially evolved in each basin. Philopatric behavioural process implies reproduction of females in their area of origin. Pickett and Pawson (1994) mentioned migrations linked to reproductive events in North Eastern Atlantic sea bass but no behavioural differences associated with sex. Differentiating among the possible isolation mechanisms requires further experimental and ecological observations, but we are nonetheless left with fewer possible mechanisms which could account for the mtDNA differentiation observed. Female hybrid breakdown and/or female philopatry are the most likely hypotheses which could account for the data and thus should be examined in the future. 


\section{An hybrid zone in Alboran Sea?}

Two observations suggest that the differentiated genomes may meet in a hybrid zone in Alboran Sea.

First, the sample from Mar Menor is significantly differentiated from all the other samples at nuclear loci and is typically Mediterranean at mitochondrial locus. Three microsatellite loci (Labrax-3, Labrax-8 and Labrax-29) cluster this sample to the Mediterranean group while the three remaining loci clusters it nearer to Atlantic samples. This may reflect differential introgression close to the hypothetical contact zone.

Second, intermediate mtDNA frequencies are observed in two samples from Alboran Sea (MMAR, MNAD). Naciri et al. (1999) suggested the Almeria-Oran oceanic front as a barrier against gene flow. The occurrence of "Mediterranean" haplotypes at higher frequencies in the Alboran Sea means that Mediterranean individuals have crossed the Almeria-Oran front. However while nuclear markers do not show apparent intermediate frequencies in these populations, as expected in the case of pure migration, they show a higher correlation coefficient between loci (Weir 1979) in the Alboran Sea (Fig. 5). This is expected in hybrid zones, where individuals from source populations are in contact but reproductive isolation mechanisms impede gene flow and maintain the genetic differentiation. In such a case, a greater correlation between loci in contact zone than in source population is observed (Barton and Hewitt 1985; 1989). Linkage disequilibria sensu stricto were not estimated because of small sample size of the two Alboran samples. Such an observation further corroborates the genetic feature of the barrier to gene flow.

Genetic divergence is often correlated with hydrographical features in the sea. Accumulating evidence suggests that such physical barriers are often insufficient to explain 
observed genetic differentiation. The comparison of genetic variation at nuclear and cytoplasmic loci for the European sea bass has enabled us to conclude that the Atlantic/Mediterranean differentiation is not only due to the Almeria-Oran front but also to other reproductive isolation processes. The physical barrier seems to rely, at least partly, on sex-biased reproductive isolation. Moreover, intermediate populations are found in the Alboran Sea. We may therefore hypothesise that the front has played a role in the localisation of the genetic barrier but not in its maintenance. It is indeed expected that hybrid zones should come to be localised in regions of limited dispersal (Barton 1979), although a physical barrier alone would be insufficient. 


\section{ACKNOWLEDGMENTS}

The authors are particularly indebted to L. Bahri-Sfar, M. Naciri and F. García de

León for their contribution to this study. They also wish to extend their thanks to P. Boudry, N. Bierne, J.-D. Durand and P. Borsa for helpful comments and Tim Sharbel for all the corrections on the manuscript. This work was financed by contract IFREMER URM n ${ }^{\circ} 16$ to F.B. 


\section{LITERATURE CITED}

Allegrucci, G., Fortunato, C., Cataudella, S., \& Sbordoni, V. 1994. Acclimation to fresh water of the sea bass: evidence of selective motality and allozyme genotypes. Pp. 486-502 in A. R. Beaumont, ed. Genetics and Evolution of Marine Organisms. Chapman and Hall, London. Allegrucci, G., Fortunato, C., \& Sbordoni, V. 1997. Genetic structure and allozyme variation of seabass (Dicentrarchus labrax and D. punctatus) in the Mediterranean Sea. Mar. Biol. 128: $347-358$.

Allegrucci, G., Caccone, A., \& Sbordoni, V. 1999. Cytochrome $b$ sequence divergence in the European sea bass (Dicentrarchus labrax) and phylogenetic relationships among some Perciformes species. J. Zool. Syst. Evol. Research 37: 149-156.

Arias, A. 1980. Crecimiento, régimen alimentario y reproducción de la dorada (Sparus aurata L.) y del róbalo (Dicentrarchus labrax L.) en los esteros de Cádiz. Invest. Pesq. 44: 59-83. Arnaud, S., Monteforte, M., Galtier, N., Bonhomme, F., \& Blanc, F. 2000. Population structure and genetic variability of pearl oyster Pinctada mazatlanica along Pacific coasts from Mexico to Panama. Cons. Genet. 1: 299-308.

Avise, J. C. 1992. Molecular population structure and the biogeographic history of a regional fauna: a case history with lessons for conservation biology. Oikos 63: 62-76.

Avise, J. C. 1994. Molecular markers, natural history and evolution. Chapman \& Hall, London.

Avise, J. C. 1998. The history and purview of phylogeography: concepts and applications. Mol. Ecol. 7: 371-380.

Avise, J. C. 2000. Phylogeography: The history and formation of species. Harvard University Press, Cambridge, MA. 
Bahri-Sfar, L., Lemaire, C., Ben Hassine, O. K., \& Bonhomme, F. 2000. Fragmentation of sea bass populations in the western and eastern Mediterranean as revealed by microsatellite polymorphism. Proc. R. Soc. Lond. B 267: 929-935.

Bandelt, H. J. \& Dress, A. W. M. 1992. Split decomposition : a new and useful approach phylogenetic analysis of distance data. Mol. Phylogenet. Evol. 1 : 242-252.

Barnabé, G. 1980. Exposé synoptique des données biologiques sur le loup ou bar, Dicentrarchus labrax. Synop.FAO Pêches: 126-70.

Barton, N. H., \& Hewitt, G. M. 1985. Analysis of hybrid zones. Annu. Rev. Ecol. Syst. 16: $113-148$.

Barton, N. H. 1979. The dynamics of hybrid zone. Heredity 43: 341-359.

Barton, N. H., \& Hewitt, G. M. 1989. Adaptation, speciation and hybrid zones. Nature 341: 497-503.

Behegaray, L. B., \& Levy, J. A. 2000. Population genetics of the silverside Odontesthes argentinensis (Teleostei, Atherinopsidae) : evidence for speciation in an estuary of southern Brazil. Copeia 2000: 441-447.

Belkhir, K., Borsa, P., Chikki, L., Goudet, J., \& Bonhomme, F. 1996-2002. Genetix v 4. 02 Un logiciel pour l'analyse des données en génétique des populations. Université Montpellier II.

Benharrat, K., Pasteur, N., Siau, Y., \& Bouain, A. 1983. Polymorphisme biochimique de Loups (Dicentrarchus labrax) originaires de quatre populations naturelles et d'un élevage. Recherches Biologiques et Aquaculture. Vol.1 Journées d'études, Montpellier. CNEXOBNDO, Brest: 1-17. 
Bermingham, E., McCafferty, S., \& Martin, A. 1997. Fish biogeography and molecular clocks: perspectives from the Panamanian Isthmus. Pp. 113-128 in T. Kocher and C. Stepien eds. Molecular Systematics of Fishes. Academic Press, San Diego, CA.

Bierne, N., David, P., Boudry, P., \& Bonhomme, F. 2002. Assortative fertilization and selection at larval stage in the mussels Mytilus edulis and M. gallorpovincialis. Evolution 56: 292-298.

Bierne (2003) choix d'habitat Proc Soc Lond

Blanquer, A., Alayse, J-P., Berrada-Rkhami, O., \& Berrebi, P. 1992. Allozyme variation in turbot (Psetta maxima) and brill (Scophthalmus rhombus) (Osteichtyes, Pleuronectiformes, Scophthalmidae) throughout their range in Europe. J. Fish Biol. 41: 725-736.

Blasquez, M., Pifferer, F., Zanuy, S., Carillo, M., \& Donaldson, E. M. 1995. Development of sex control techniques for european sea bass (Dicentrarchus labrax L.) aquaculture: effects of dietary $17 \alpha$-methyl testosterone prior to sex differentiation. Aquaculture 135: 329-342.

Bonhomme F., Naciri, M., Bahri-Sfar, L. \& Lemaire, C. 2002. Comparative analysis of genetic structure of two closely related sympatric marine fish species Dicentrarchus labrax and Dicentrarchus punctatus. C. R. A. S. 325: 213-220.

Borsa, P., Jarne, P., Belkhir, K. \& Bonhomme, F. 1994. Genetic structure of the palourde Ruditapes decussatus L. in the Mediterranean. Pp. 102-113 in A. R. Beaumont ed. Genetics and evolution of aquatic organisms. Chapman \& Hall, London, U.K.

Borsa, P., Naciri, M., Bahri, L., Chikhi, L., García de León, F. J. \& Bonhomme, F. 1997. Zoogéographie infra-spécifique de la mer Méditerranée, analyse des données génétiques sur seize espèces atlanto-méditerranéennes (poissons et invertébrés). Vie et Milieu 47: 295-305. 
Bowen, B. W., \& Grant, W. S. 1997. Phylogeography of the sardines (Sardinops spp.): assessing biogeographic models and population histories in temperature upwelling zones. Evolution 51: 1601-1610.

Briggs, J. C. 1974. Marine zoogeography. McGraw-Hill, New York.

Brown, W. M., George Jr, M.. \& Wilson, A. C. 1979. Rapid evolution of animal mitochondrial DNA. Proc. Natl. Acad. Sci. USA 76: 1967-1971.

Bruslé, J. \& Roblin, C. 1984. Sexualité du loup Dicentrarchus labrax en condition d'élévage controlé. Pp. 33-43 in G. Barnabé and R. Billard eds. Aquaculture du bar et des sparidés. INRA publ. Paris.

Buonaccorsi, V. P., Reece, K. S., Morgan, L. W. \& Graves, J.E. 1999. Geographic distribution of molecular markers within the blue marlin (Makaira nigricans): a hierarchical analysis of allozyme, single copy nuclear DNA and mitochondrial DNA markers. Evolution $53: 568-579$.

Buonaccorsi, V. P., McDowell, J. R. \& Graves, J. E. 2001. Reconciling patterns of interocean molecular variance from four classes of molecular markers in blue marlin (Makaira nigricans). Mol. Ecol. 10: 1179-1196.

Burton, R. S. 1998. Intraspecific phylogeography across the Point Conception biogeographic boundary. Evolution 52: 734-745.

Burton, R. S., Rawson, P. D. \& Edmands, S. 1999. Genetic architecture of physiological phenotypes: empirical evidence for coadapted gene complexes. Am. Zool. 39: 451-62. Caccone, A., Allegrucci, G., Fortunato, C. \& Sbordoni, V. 1997. Genetic differentiation within the european sea bass (D. labrax) as revealed by RAPD-PCR assays. J. Hered. 88: 316-324. 
Carlon, D.B. \& Budd, A.F. 2002. Incipient speciation across a depth gradient in a scleractinian coral. Evolution, 56: 2227-2242.

Cesaroni, D., Venanzetti, F., Allegrucci, G. \& Sbordoni, V. 1997. Mitochondrial DNA length variation and heteroplasmy in natural populations of the european sea bass, Dicentrarchus labrax. Mol. Biol Evol. 14: 560-568.

Clark, A. G. \& Lyckegaard, E. M. S. 1988. Natural selection with nuclear and cytoplasmic transmission, III. Joint analysis of segregation and mitochondrial DNA in Drosophila melanogaster. Genetics 118: 471-481.

Cunningham, C. W. \& Collins, T. M. 1994. Developing model systems for molecular biogeography: Vicariance and interchange in marine invertebrates. B. Schierwater, B. Streit, G. P. Wagner, and R. DeSalle, eds. Pp. 405-433. Basel: Birkhäuser verlag.

De Metrio G. 1995. Characterization of large pelagic stocks (Thunnus thynnus L., Thunnus alalunga Bonn., Sarda sarda Bloch, Xiphias gladius L.) in the Mediterranean. Final draft report to the Commission of the European Communities, Directorate General for Fisheries (DG XIV), Community of Mediterranean Universities, Bari, 118p.

Dieckmann, U.\& Doebeli, M. 1999. On the origin of species by sympatric speciation. Nature 400: 354-357.

Duffy, J.E. 1996. Resource-associated population subdivision in a symbiotic coral-reef shrimp. Evolution 50: 360-373.

Estoup, A., Tailliez, C., Cornuet, J. M. \& Solignac, M.. 1995. Size homoplazy and mutational processes of interrupted microsatellites in two bee species, Apes mellifera and Bombus terrestris. Mol. Biol. Evol. 12: 1074-1084.

Estoup, A., Jarne, P. \& Cornuet, J. M. 2002. Homoplasy and mutation model at microsatellite loci and their consequences for population genetics analysis. Mol. Ecol. 11: 1591-1604. 
Excoffier, L., Smouse, P. E., \& Quattro, J. M. 1992. Analysis of molecular variance inferred from metric distances among DNA haplotypes: application to human mitochondrial DNA restriction data. Genetics 131: 479-91.

Felsenstein, J. 1993. Phylip 3.5 (Phylogeny Inference Package), University of Washington, Seattle, Washington, USA.

Fitzsimmons, N. N., Moritz, C., Limpus, C. J., Pope, L. \& Prince, R. 1997a. Geographic structure of mitochondrial and nuclear gene polymorphisms in australian green turtle populations and male-biased gene flow. Genetics 147: 1843-1854.

Fitzsimmons, N. N., Limpus, C., Norman, J. A., Goldizen, A. R., Miller, J. D. \& Moritz, C. 1997b. Philopatry of male marine turtles inferred from mitochondrial markers. Proc. Natl. Acad. Sci. USA 94: 8912-8917.

García de León, F. 1995. Marqueurs hypervariables chez le loup (Dicentrarchus labrax): applications aux programmes d'amélioration génétique et à l'étude des populations naturelles. Ph.D diss. Université Montpellier II, Montpellier, France.

García de León, F., Dallas, J., Chatain, B., Canone, M., Versini, J. \& Bonhomme, F. 1995.

Development and use of microsatellite markers in sea bass, Dicentrarchus labrax (Perciformes Serranidae). Mol. Mar. Biol. Biotech 4: 62-68

García de León, F., Chikhi, L. \& Bonhomme, F. 1997. Microsatellite polymorphism and population subdivision in natural populations of European sea bass Dicentrarcus labrax (L. 1758). Mol. Ecol. 6: 51-62.

Garza, J. C. \& Freimer, N. B. 1996. Homoplasy for size at microsatellite loci in humans and chimpanzees. Genome Res. 6: 211-217.

Gavrilets, S., Li, H., \& Vose, M. D. 2000. Patterns of parapatric speciation. Evolution 54: 1126-1134. 
Gerber, A. S., Loggins R., Kumar, S. \& Dowling, T. E. 2001. Does neutral evolution shape observed patterns of DNA variation in animal mitochondrial genomes? Annu. Rev. Genet. 35: $539-566$.

Guttiriez, P. C. 1994. Mitochondrial-DNA polymorphism in the oilbird (Steatornis caripensis, steatornithidae) in Venezuela. Auk 111: 573-578.

Hall, T. A. 1999. BioEdit: a user-friendly biological sequence alignment editor and analysis program for Windows 95/98/NT. Nucl. Acids. Symp. Ser. 41: 95-98.

Harrison, R. G. 1990. Hybrid zones: windows on evolutionary processes. Oxf. Surv. Evol. Biol. 7: 69-128.

Hedrick, PW. 1999. Perspective: highly variable loci and their interpretation in evolution and conservation. Evolution 53: 313-318.

Hull, S. L. 1998. Assortative mating between two distinct micro-allopatric populations of Littorina saxatilis (Olivi) on the northeast coast of England. Hydrobiologia 378: 79-88.

Huson, D.H. 1998. SplitsTree: a program for analyzing and visualizing evolutionary data. Bioinformatics 14:1:68-73.

Huvet, A., Lapègue, S., Magoulas, A. \& Boudry, P. 2000. Mitochondrial and nuclear DNA phylogeography of Crassostrea angulata, the Portuguese oyster endangered in Europe. Cons. Gen. 1: 251-262.

Jarne, P. \& Lagoda, P. J. L. 1996. Microsatellites, from molecules to populations and back. Trends Ecol. Evol. 11: 424-429.

Kimura, M. 1980. A simple method for estimating evolutionnary rates of base substitutions through comparative studies of nucleotides sequences. J. Mol. Evol. 16: 111-120.

Kirkpatrick, M. 2000. Fish found in flagrante delicto. Nature 408: 298-299. 
M. Kirkpatrick and V. Ravigné. 2002. Speciation by Natural and Sexual Selection. Am. Nat. 159:22-35

Knowlton, N., Weight, L. A., Solorzano, L. A., Mills, D. K. \& Bermingham, E. 1993.

Divergence in proteins, mitochondrial DNA, and reproductive compatibility across the Isthmus of Panama. Science 260: 1629-1631.

Kumar S., Tamura, K., Jakobsen, I. B. \& Nei, M. 2001 MEGA2: Molecular Evolutionary Genetics Analysis software. Bioinformatics. 17:1244-1245.

Launey, S., Ledu, C., Boudry, P., Bonhomme, F. \& Naciri-Graven, Y. 2002. Geographic structure in the European flat oyster, Ostrea edulis L, as revealed by microsatellite polymorphism. J. Hered. 93: 331-351.

Lee, C. E. 2000. Global phylogeography of a cryptic copepod species complex and reproductive isolation between genetically proximate "populations". Evolution 54: 2014-2027. Lemaire, C., Allegrucci, G., Naciri, M., Bahri-Sfar, L., Kara, H. \& Bonhomme, F. 2000. Do discrepancies between microsatellite and allozyme variation reveal differential selection between sea and lagoon in the sea bass (Dicentrarchus labrax)? Mol Ecol 9: 457-67.

Lessios, H. A., Kessing, B. D. \& Robertson, D. R. 1998. Massive gene flow across the world's most potent marine biogeographic barrier. Proc. Soc. Lond. B 265: 583-588.

Lyrholm, T., Leimar, O., Johanneson, B. \& Gyllensten, U. 1999.Sex-biased dispersal in sperm whales: contrasting mitochondrial and nuclear genetic structure of global populations.

Proc. R. Soc. Lond. B 266: 347-354.

McDonald, J. H. 1994. Detecting natural selection by comparing geographic variation in protein and DNA polymorphisms. Pp.88-101 in B. Golding, ed. Non-neutral evolution. Theories and molecular data. Chapman and Hall, NewYork. 
Melnick, D. J., \& Hoelzer, G. A.. 1992. Differences in male and female macaque dispersal lead to contrasting distributions of nuclear and mitochondrial DNA variation. Int. J. Primatol. 13: 379-393.

Mokady, O. \& Brickner, I. 2001. Host-associated speciation in a coral-inhabiting barnacle. Mol. Biol. Evol. 18: 975-981.

Muss, A., Robertson, D. R., Stepien, C. A., Wirtz, P. \& Bowen, B. W. 2001. Phylogeography of Ophioblennius: the role of ocean currents and geography in reef evolution. Evolution 55: 561-572.

Naciri, M., Lemaire, C., Borsa, P. \& Bonhomme, F. 1999. Genetic study of the Atlantic/Mediterranean transition in sea bass (Dicentrarchus labrax). J. Hered. 90: 591-596. Nagel, L. \& Schluter, D. 1998. Body size, naturale selection and speciation in stickelbacks. Evolution 52: 209-218.

Nei, M. 1987. Molecular evolutionary genetics. Columbia Univ. Press, New York. Nei, M. \& Li, W. H. 1979Mathematical model for studying genetic variation in terms of restriction endonucleases. Proc. Natl. Acad. Sci. U.S.A. 76: 5269-5273.

Nielsen, R. \& Wakeley, J. 2001. Distinguishing migration from isolation: a markov chain Monte Carlo approach. Genetics 158: 885-896.

Posada, D. \& Crandall, K. A. 2001. Intraspecific gene genealogies: trees grafting into networks. Trends Ecol. Evol. 16: 37-45.

Orita, M., Iwahana, H., Kanazawa, H., Hayashi, K. \& Sekiya, T. 1989. Detection of polymorphisms of human DNA by gel electrophoresis as single-strand conformation polymorphisms. Proc Natl Acad Sci U S A 86: 2766-2770.

Orr, M. R. \& Smith, T. B. 1998. Ecology and speciation. Trends Ecol. Evol. 13: 502-506. 
Palumbi, S. R. 1994. Genetic divergence, reproductive isolation and marine speciation. Annu. Rev. Ecol. Syst. 25: 547-572.

Palumbi, S. R. 1996. Microspatial genetic structure and speciation in marine taxa with high dispersal abilities in F. J. D. et S. R. Palumbi, eds. Molecular Zoology. Advances, strategy and protocols. Wiley-Liss, New York.

Palumbi, S. R. \& Baker, C. S. 1994. Contrasting population structure from nuclear intron sequences and mtDNA of humpback whales. Mol Biol Evol 11: 426-35.

Patarnello, T., Bargelloni, L., Caldera, F. \& Colombo, L. 1993. Mitochondrial DNA sequence variation in the european sea bass Dicentrarchus labrax L. (Serranidae) evidence of differential haplotype distribution in natural and farmed population. Mol. Mar. Biol. Biotech. 2: $333-337$.

Patton, J. C., Gallaway, B. J., Fechhelm, R. G. \& Cronin, M. A. 1997. Genetic variation of microsatellite and mitochondrial DNA markers in broad whitefish (Coregonus nasus) in the Colville and Sagavanirktok Rivers in northern Alaska. Can. J. Fish. Aquat. Sci. 54: 15481556.

Perrin C. \& Borsa, P. 2001. Mitochondrial DNA Analysis of the geographic structure of indian scad mackerel, Decapterus russelli (Carangidae) in the Indo-Malay Archipelago. J. Fish Biol. 59: 1421-1426.

Pickett, G. D \& Pawson, M. G. 1994. Sea bass, biology, exploitation and conservation. Chapman \& Hall, London.

Planes, S.\& Fauvelot, C. 2002. Isolation by distance and vicariance drive genetic structure of a coral reef fish in the Pacific Ocean. Evolution 56: 378-399.

Rand, D. M. 2001. The units of selection on mitochondrial DNA. Annu. Rev. Ecol. Syst. 32: 415-448. 
Reynolds, J., Weir, B. S. \& Cockerham, C. C. 1983. Estimation of the coancestry coefficient, basis for a short term genetic distance. Genetics 105: 767-779.

Rice, W. 1989. Analysis tables of statistical tests. Evolution 43: 223-225.

Rieseberg, L. H., Whitton, J. \& Gardner, K. 1999. Hybrid zones and the genetic architecture of a barrier to gene flow between two sunflower species. Genetics 152:713-27.

Rocha, L. A., Bass, A. L., Robertson, D. R. \& Bowen, B. W. 2002. Adult habitat preference, larval dispersal, and the comparative phylogeography of three Atlantic surgeonfishes (Teleostei: Acanthuridae). Mol. Ecol. 11: 243-252.

Rundle, H.D. \& Schluter, D. 2002. Natural selection and speciation in sticklebacks from beginning to end. Pp 000-000 in U. Dieckmann, H. Metz, M. Doebeli and D. Tautz eds. Adaptive Speciation. Cambridge University Press, Cambridge.

Saillant, E., Fostier, A., Haffray, P., Menu, B., Thimonier, J. \& Chatain, B. 2002.

Temperature effects and genotype-temperature interactions on sex determination in the European Sea Bass (Dicentrarchus labrax L.). J. Exp. Zool. 292: 494-505.

Saillant, E., Fostier, A., Haffray, P., Menu, B. \& Chatain, B. 2003. Saline preferendum for the European sea bass, Dicentrarchus labrax, larvae and juveniles: effect of salinity on early development and sex determination. J.Exp. Mar. Biol. Ecol. 26: 103-117.

Sanger, F., Niklens, S. \& Coulson, A. R. 1977. DNA sequencing with chain terminating inhibitors. Proc Natl Acad Sci U S A 74: 5463-5467.

Schmidt, P. S., Bertness, M. D. \& Rand, D. M. 2000. Environmental heterogeneity and balancing selection in the acorn barnacle Semibalanus balanoides. Proc. R. Soc. Lond. B 267: $379-384$. 
Schneider, S., Roessli, D. \& Excoffier, L. 2000. Arlequin ver. 2000 A software for population genetics data analysis. Genetic and Biometry Laboratory, Dept of Anthropology and Ecology, Université de Genève.

Slatkin, M. 1985. Gene flow in natural populations. Ann. Rev. Ecol. Syst. 16: 393-430.

Slatkin, M. 1995. A measure of population subdivision based on microsatellite allele frequencies. Genetics 139: 457-7462.

Tajima, F. 1983. Evolutionnary relationship of DNA sequences in finite populations. Genetics 105: 585-595.

Tajima, F. 1989. The effect of change in population size on DNA polymorphism. Genetics. 123: 597-601.

Tamura, K. \& Nei, M. 1993. Estimation of the number of nucleotide substitutions in the control region of mitochondrial DNA in human and chimpanzees. Mol Biol Evol 10: 512-526. Taylor, E. B., Harvey, S., Pollard, S. \& Volpe, J. 1997. Postglacial genetic differentiation of reproductive ecotypes of kokanee Oncorhyncus nerka in Okanagan Lake, British Columbia. Mol. Ecol. 6: 503-517.

Via, S. 2001. Sympatric speciation in animals : the ugly duckling grows up. Trends Ecol. Evol. 17: 381-390.

Viard, F., Franck, P., Dupois, M. P., Estoup, A. \& Jarne, P. 1998. Variation of microsatellite size homoplasy across electromorphs, loci, and populations in three invertebrate species. $J$. Mol. Evol. 47: 42-51.

Weir, B. 1979. Inferences about linkage disequilibrium. Biometrics 35: 235-254.

Weir, B. \& Cockerham, C. 1984. Estimating F-statistics for the analysis of population structure. Evolution 38: 1358-1370. 


\section{LEMAIRE ET AL.}

Table 1 : Description of the 18 D. labrax samples by geographic origin, code, sample size, habitat, date of collection, collector and (1) García de León et al. (1997), (2) Naciri et al. (1999) ; (3) Bahri-Sfar et al. (2000) ; (4) Lemaire et al. (2000), P.S. : Present Stud:

\begin{tabular}{|c|c|c|c|c|c|c|}
\hline Geographic origin & Locality & Code & $N$ & Habitat & Sampling date & Co \\
\hline North Sea & Antwerpen, Belgium & BANV & 50 & Sea & Sep. 1997 & F. \\
\hline \multirow[t]{6}{*}{ Atlantic Ocean } & St Brieuc, France & FBRE & 39 & Lagoon & Aug. 1994 & Y. \\
\hline & Ile d'Yeu, France & FYEU & 23 & Sear & Mar. 2000 & C. \\
\hline & Aveiro, Portugal & PAVR & 50 & Lagoon & --- & $\mathrm{R}$. \\
\hline & Tanger 1, Morocco & MTN1 & 35 & Sea & Jan. 1997 & M. \\
\hline & Tahadarte 1, Morocco & MTH1 & 30 & Sea & Dec. 1997 & M. \\
\hline & Rabat, Morocco & MRBT & 60 & Sea & Jun 1996 & M. \\
\hline \multirow[t]{3}{*}{ Alboran Sea } & Ksar-Sghir 1, Morocco & MKS1 & 46 & Sea & Feb. 1997 & M. \\
\hline & Martil, Morocco & MMAR & 20 & Sea & Mar. 1997 & M. \\
\hline & Nador, Morocco & MNAD & 9 & Lagoon & Dec. 1996 & M. \\
\hline \multirow[t]{8}{*}{ Western Mediterranean } & Mar Menor, Spain & $E M A M$ & 36 & Lagoon & Dec. 1999 & E. \\
\hline & Prevost, France & FPRE & 24 & Lagoon & Oct. 1994 & F.J \\
\hline & Sète, France & FSET & 26 & Sea & Oct. 1994 & F.J \\
\hline & Marseille, France & FMRS & 50 & Sea & Feb. 1994 & F.J \\
\hline & Annaba, Algeria & $A G L A$ & 34 & Sea & Jan. 1994 & $\mathrm{H}$. \\
\hline & Iskheul, Tunisia & TISK & 40 & Lagoon & Jan. 1997 & L. \\
\hline & Bizerte, Tunisia & TBIZ & 54 & Lagoon & Feb. 1997 & $\mathrm{~L}$. \\
\hline & La Goulette, Tunisia & $T G O U$ & 32 & Sea & Apr. 1997 & L. \\
\hline
\end{tabular}


LEMAIRE ET AL.

Table 2 : Mitochondrial haplotype frequencies and diversities $\left(H e_{n . b}:\right.$ haplotypic diversity; $\pi$ : nucleot

\begin{tabular}{|c|c|c|c|c|c|c|c|c|c|c|}
\hline \multirow[b]{2}{*}{ Samples } & \multirow[b]{2}{*}{$N$} & \multicolumn{7}{|c|}{ HAPLOTYPES } & \multirow[b]{2}{*}{ He n.b. } & \multirow[b]{2}{*}{$\pi$} \\
\hline & & A & B & $\mathrm{C}$ & $\mathrm{D}$ & $\mathrm{E}$ & $\mathrm{F}$ & G & & \\
\hline BANV & 41 & 0.93 & & 0.02 & 0.02 & & 0.02 & & 0.14 & 2.0 .10 \\
\hline FBRE & 38 & 0.79 & 0.16 & & 0.05 & & & & 0.36 & 4.0 .10 \\
\hline FYEU & 22 & 0.77 & 0.09 & 0.05 & 0.09 & & & & 0.40 & 5.0 .10 \\
\hline PAVR & 48 & 0.79 & 0.08 & & 0.02 & 0.02 & & 0.08 & 0.37 & 5.0 .10 \\
\hline MTAN & 42 & 0.69 & 0.26 & 0.02 & 0.02 & & & & 0.46 & 6.0 .10 \\
\hline MTAH & 31 & 0.68 & 0.26 & & 0.06 & & & & 0.49 & 6.0 .10 \\
\hline MRBT & 35 & 0.71 & 0.26 & & 0.03 & & & & 0.44 & 5.0 .10 \\
\hline MKSR & 43 & 0.79 & 0.14 & 0.02 & 0.02 & 0.02 & & & 0.36 & 5.0 .10 \\
\hline MMAR & 14 & 0.57 & 0.43 & & & & & & 0.53 & 7.0 .10 \\
\hline MNAD & 9 & 0.22 & 0.56 & & & 0.11 & & 0.11 & 0.69 & 1.0 .10 \\
\hline$E M A M$ & 32 & & 0.97 & & & 0.03 & & & 0.06 & 2.0 .10 \\
\hline FPRE & 20 & & 0.95 & & & 0.05 & & & 0.10 & 4.0 .10 \\
\hline FSET & 14 & & 1.00 & & & & & & -- & -- \\
\hline FMRS & 60 & & 0.95 & & & 0.05 & & & 0.10 & 4.0 .10 \\
\hline AGLA & 51 & 0.02 & 0.98 & & & & & & 0.04 & 5.0 .10 \\
\hline TISK & 38 & & 0.92 & & & 0.08 & & & 0.15 & 6.0 .10 \\
\hline TBIZ & 29 & 0.14 & 0.83 & & & 0.03 & & & 0.31 & 3.0 .10 \\
\hline$T G O U$ & 27 & & 0.96 & & & 0.04 & & & 0.07 & 3.0 .10 \\
\hline Atlantic \& Alboran & 323 & 0.69 & 0.22 & 0.01 & 0.03 & 0.02 & & 0.02 & 0.42 & 5.5 .10 \\
\hline Western Mediterranean & 271 & 0.02 & 0.95 & & & 0.04 & & & 0.10 & 6.7 .10 \\
\hline
\end{tabular}


LEMAIRE ET AL.

Table 3 : Genetic variability and $f$ estimates at 6 microsatellite loci in Dicentrarchux labrax samples. Le $p<0.01 ; * * * p<0.001$.

\begin{tabular}{|c|c|c|c|c|c|c|c|c|c|}
\hline \multirow[b]{2}{*}{ Samples } & \multirow[b]{2}{*}{$H_{\text {exp }}$} & \multirow[b]{2}{*}{$H_{o b s}$} & \multicolumn{6}{|c|}{$f$} & \multirow[b]{2}{*}{$\mathrm{Al}$} \\
\hline & & & Labrax-3 & Labrax-6 & Labrax-8 & Labrax-13 & Labrax-17 & Labrax-29 & \\
\hline BANV & 0.89 & 0.86 & 0.063 & 0.028 & 0.048 & -0.024 & 0.064 & 0.005 & $0 . \mathrm{C}$ \\
\hline FBRE & 0.89 & 0.84 & 0.061 & 0.111 & 0.078 & 0.003 & 0.107 & 0.02 & $0 . C$ \\
\hline FYEU & 0.87 & 0.88 & 0.154 & -0.128 & 0.082 & 0.004 & -0.115 & -0.067 & -0 . \\
\hline PAVR & 0.91 & 0.80 & 0.127 & $0.200^{*}$ & $0.130^{*}$ & 0.111 & 0.118 & 0.048 & 0.1 \\
\hline MTN1 & 0.88 & 0.83 & 0.101 & 0.197 & 0.023 & 0.025 & 0.022 & 0.020 & $0 . C$ \\
\hline MTH1 & 0.89 & 0.80 & 0.024 & 0.197 & 0.028 & 0.070 & 0.152 & 0.144 & 0.1 \\
\hline MRBT & 0.90 & 0.89 & -0.03 & 0.148 & -0.073 & -0.051 & 0.016 & 0.015 & $0 . C$ \\
\hline MKS1 & 0.89 & 0.9 & 0.023 & 0.064 & -0.079 & -0.054 & -0.018 & 0.058 & -0 . \\
\hline MMAR & 0.89 & 0.84 & -0.062 & 0.089 & 0.013 & 0.055 & 0.194 & $0.192 *$ & $0 . C$ \\
\hline MNAD & 0.89 & 0.89 & 0.111 & -0.085 & -0.051 & -0.008 & 0.000 & 0.052 & $0 . C$ \\
\hline EMAM & 0.87 & 0.84 & 0.020 & $0.260^{*}$ & -0.077 & -0.045 & 0.046 & -0.021 & $0 . C$ \\
\hline FPRE & 0.86 & 0.81 & 0.019 & $0.49^{*}$ & 0.021 & -0.023 & -0.036 & -0.016 & $0 . C$ \\
\hline FSET & 0.87 & 0.83 & -0.008 & $0.42 *$ & -0.098 & -0.046 & 0.010 & -0.008 & $0 . C$ \\
\hline$F M R S$ & 0.85 & 0.82 & 0.051 & $0.36^{*}$ & 0.081 & -0.097 & 0.000 & -0.071 & $0 . \mathrm{C}$ \\
\hline$A G L A$ & 0.85 & 0.82 & -0.067 & $0.46^{*}$ & 0.055 & -0.022 & -0.138 & -0.038 & $0 . C$ \\
\hline TISK & 0.84 & 0.76 & -0.021 & $0.33^{*}$ & $0.16015^{*}$ & -0.006 & 0.106 & 0.035 & $0 . \mathrm{C}$ \\
\hline$T B I Z$ & 0.85 & 0.79 & 0.06 & 0.294 & -0.044 & 0.065 & 0.011 & 0.092 & $0 . \mathrm{C}$ \\
\hline$T G O U$ & 0.84 & 0.84 & 0.07 & $0.58^{*}$ & -0.139 & 0.101 & 0.083 & -0.051 & $0 . C$ \\
\hline Atlantic \& Alboran & 0.90 & 0.85 & $0.058 * * *$ & $0.141 * * *$ & $0.028^{*}$ & 0.005 & $0.057^{*}$ & $0.051 * * *$ & $0 . \mathrm{C}$ \\
\hline Western Mediterranean & 0.86 & 0.81 & 0.017 & $0.411^{* * *}$ & 0.008 & -0.012 & 0.011 & 0.001 & $0 . \mathrm{C}$ \\
\hline
\end{tabular}




\section{LEMAIRE ET AL.}

Table 4 : Matrix of pairwise estimates of q. Above matrix : Microsatellite loci. Below matrix : Cytochrome indicated in bold. Estimates significant after Bonferroni adjustment are underlined. NC : Non Computed (no 1

\begin{tabular}{|c|c|c|c|c|c|c|c|c|c|c|c|c|c|c|}
\hline & BANV & FBRE & FYEU & PAVR & MTN1 & MTH1 & MRBT & MKS1 & MMAR & MNAD & EMAM & FPRE & FSET & $F$ \\
\hline BANV & & $\underline{0 . .008}$ & 0.005 & $\underline{0.010}$ & $\underline{0.014}$ & $\underline{0.020}$ & $\underline{0.009}$ & $\underline{0.014}$ & 0.008 & 0.024 & $\underline{0.034}$ & $\underline{0.030}$ & $\underline{0.036}$ & $\underline{\mathbf{0}}$. \\
\hline FBRE & 0.063 & & 0.007 & 0.001 & 0.003 & $\underline{0.011}$ & 0.004 & $\underline{0.008}$ & 0.001 & 0.018 & $\underline{0.025}$ & $\underline{0.026}$ & $\underline{0.021}$ & $\underline{\mathbf{0}}$. \\
\hline FYEU & 0.044 & -0.025 & & $\underline{0.015}$ & 0.008 & 0.011 & 0.007 & $\underline{0.011}$ & -0.005 & 0.025 & $\underline{0.023}$ & $\underline{0.031}$ & $\underline{0.028}$ & $\underline{\mathbf{0}}$. \\
\hline PAVR & 0.040 & -0.004 & -0.014 & & 0.006 & 0.007 & $\underline{0.008}$ & 0.004 & 0.002 & 0.007 & $\underline{0.021}$ & $\underline{0.015}$ & $\underline{0.012}$ & $\underline{\mathbf{0}}$. \\
\hline MTN1 & $\underline{0.153}$ & 0.002 & 0.011 & 0.037 & & 0.006 & 0.005 & $\underline{0.010}$ & -0.004 & 0.029 & $\underline{0.012}$ & $\underline{0.021}$ & $\underline{0.015}$ & $\underline{\mathbf{0}}$. \\
\hline MTH1 & 0.166 & -0.002 & 0.005 & 0.036 & -0.026 & & 0.007 & $\underline{0.012}$ & -0.006 & 0.016 & 0.010 & $\underline{0.018}$ & $\underline{0.009}$ & $\underline{\mathbf{0}}$. \\
\hline MRBT & 0.150 & -0.007 & 0.007 & 0.030 & -0.026 & -0.028 & & $\underline{0.009}$ & 0.001 & $\underline{0.024}$ & $\underline{0.018}$ & $\underline{0.023}$ & $\underline{0.018}$ & $\underline{\mathbf{0}}$. \\
\hline MKS1 & 0.050 & -0.022 & -0.024 & -0.007 & 0.007 & 0.008 & 0.000 & & 0.004 & 0.004 & $\underline{0.025}$ & $\underline{0.017}$ & $\underline{0.017}$ & $\underline{\mathbf{0}}$. \\
\hline MMAR & 0.379 & 0.095 & 0.111 & 0.147 & -0.003 & -0.007 & 0.005 & 0.106 & & 0.009 & 0.016 & 0.017 & 0.011 & 0. \\
\hline MNAD & $\underline{0.630}$ & 0.350 & 0.331 & 0.378 & 0.208 & 0.190 & 0.230 & 0.357 & 0.044 & & $\underline{0.044}$ & 0.021 & 0.021 & $\underline{\mathbf{0}}$ \\
\hline EMAM & $\underline{0.893}$ & $\underline{0.740}$ & $\underline{0.773}$ & $\underline{0.741}$ & $\underline{0.623}$ & $\underline{0.637}$ & $\underline{0.661}$ & $\underline{0.735}$ & 0.600 & 0.355 & & $\underline{0.017}$ & $\underline{0.008}$ & $\underline{\mathbf{0}}$. \\
\hline FPRE & $\underline{0.872}$ & $\underline{0.695}$ & $\underline{0.719}$ & $\underline{0.702}$ & $\underline{0.571}$ & $\underline{0.577}$ & $\underline{0.606}$ & $\underline{0.693}$ & 0.509 & 0.242 & -0.037 & & -0.005 & $\underline{\mathbf{0}}$. \\
\hline FSET & $\mathrm{NC}$ & $\mathrm{NC}$ & $\mathrm{NC}$ & $\mathrm{NC}$ & $\mathrm{NC}$ & $\mathrm{NC}$ & $\mathrm{NC}$ & $\mathrm{NC}$ & $\mathrm{NC}$ & $\mathrm{NC}$ & $\mathrm{NC}$ & $\mathrm{NC}$ & & 0. \\
\hline FMRS & $\underline{0.884}$ & $\underline{0.759}$ & $\underline{0.791}$ & $\underline{0.761}$ & $\underline{0.656}$ & $\underline{0.672}$ & $\underline{0.691}$ & $\underline{0.755}$ & $\underline{0.627}$ & 0.373 & -0.020 & -0.034 & $\mathrm{NC}$ & \\
\hline$A G L A$ & $\underline{0.913}$ & $\underline{0.783}$ & $\underline{0.822}$ & $\underline{0.780}$ & $\underline{0.675}$ & $\underline{0.696}$ & $\underline{0.714}$ & $\underline{0.776}$ & 0.681 & 0.469 & -0.010 & -0.001 & $\mathrm{NC}$ & 0. \\
\hline TISK & $\underline{0.854}$ & $\underline{0.703}$ & $\underline{0.727}$ & $\underline{0.710}$ & $\underline{0.589}$ & $\underline{0.598}$ & $\underline{0.622}$ & $\underline{0.700}$ & $\underline{0.527}$ & 0.248 & -0.008 & -0.033 & $\mathrm{NC}$ & -( \\
\hline$T B I Z$ & $\underline{0.756}$ & $\underline{0.561}$ & $\underline{0.572}$ & $\underline{0.585}$ & $\underline{0.430}$ & $\underline{0.427}$ & $\underline{0.458}$ & $\underline{0.565}$ & 0.291 & 0.051 & 0.071 & 0.034 & $\mathrm{NC}$ & $\mathbf{0}$. \\
\hline TGOU & $\underline{0.885}$ & $\underline{0.723}$ & $\underline{0.754}$ & $\underline{0.727}$ & $\underline{0.603}$ & $\underline{0.615}$ & $\underline{0.640}$ & $\underline{0.719}$ & 0.567 & 0.313 & -0.035 & -0.043 & $\mathrm{NC}$ & -( \\
\hline
\end{tabular}


Table 5 : Estimates of nucleotidic divergence on a $238 \mathrm{bp}$ of the mitochondrial cytochrome $b$ of D. labrax. Above diagonal :distances of Kimura 2 parameters ; below diagonal : number of pairwise changes.

\begin{tabular}{lllllllll} 
& A & B & C & D & E & F & G & D. Punct \\
\hline A & - & 0.013 & 0.021 & 0.008 & 0.017 & 0.017 & 0.013 & 0.121 \\
B & 3 & - & 0.008 & 0.021 & 0.004 & 0.03 & 0.026 & 0.137 \\
C & 5 & 2 & - & 0.03 & 0.004 & 0.039 & 0.035 & 0.148 \\
D & 2 & 5 & 7 & - & 0.026 & 0.026 & 0.021 & 0.131 \\
E & 4 & 1 & 1 & 6 & - & 0.035 & 0.03 & 0.143 \\
F & 4 & 7 & 9 & 6 & 8 & - & 0.017 & 0.131 \\
G & 3 & 6 & 8 & 5 & 7 & 4 & - & 0.131 \\
D. punct & 26 & 29 & 31 & 28 & 30 & 28 & 28 & - \\
\hline
\end{tabular}




\section{LEGENDS FOR FIGURES :}

Figure 1 : Geographic location of the 18 samples of D. labrax.

Figure 2 : Mitochondrial haplotype frequencies in the 18 samples of Dicentrarchus labrax. Rare haplotypes present in Atlantic samples were combined under the "Atlantic pool".

Figure 3 : Neighbour joining tree inferred from Reynolds's genetic distance at 6 microsatellite loci in 18 Dicentrarchus labrax samples. Only bootstrap scores greater than $50 \%$ are indicated.

Figure 4 : Split decomposition network of D. labrax rooted with haplotype of $D$. punctatus. Haplotypes typical of Mediterranean Sea are indicated in bold italic.

Figure 5 : Average of the coefficient of correlation between loci (Rij) (Weir, 1979) at the 18 samples of Dicentrarchus labrax. 
LEMAIRE ET AL

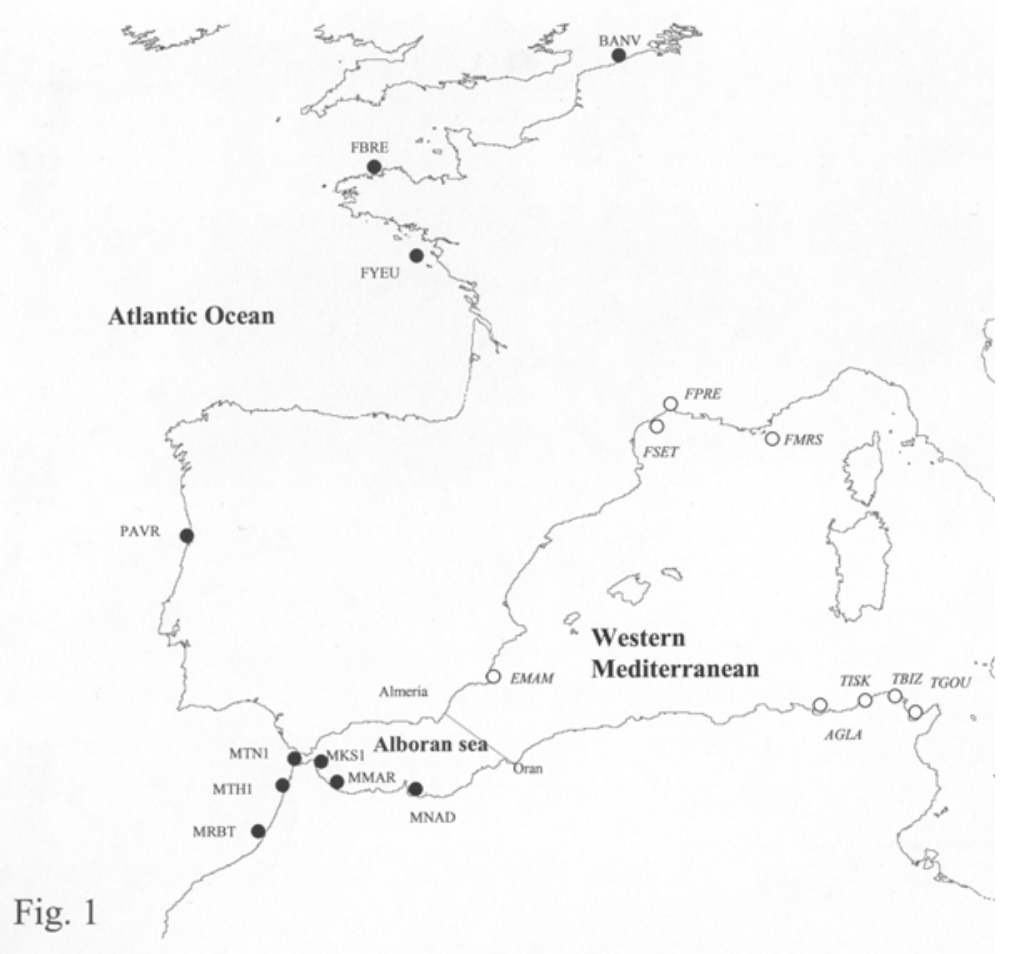


LEMAIRE ET AL

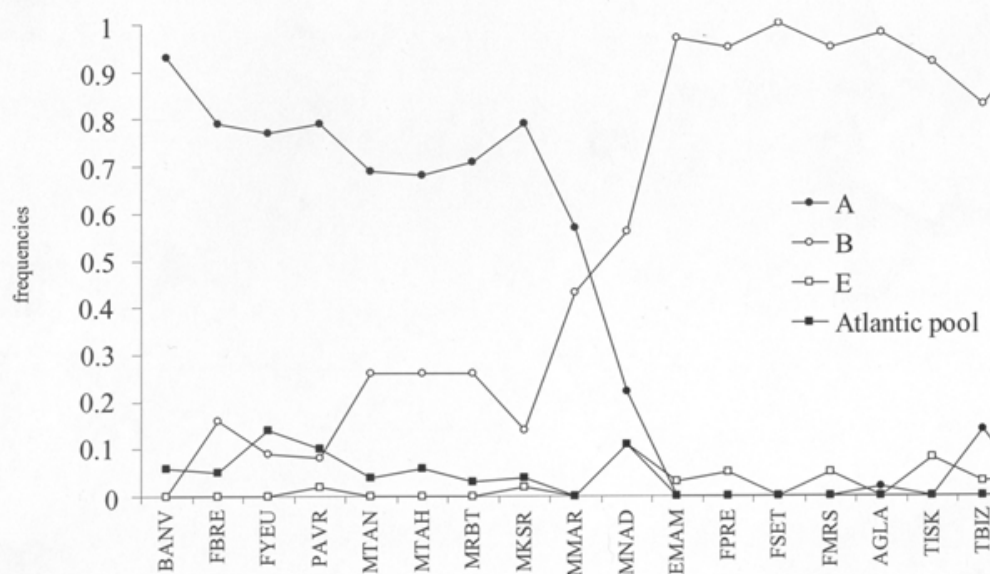

Fig. 2 


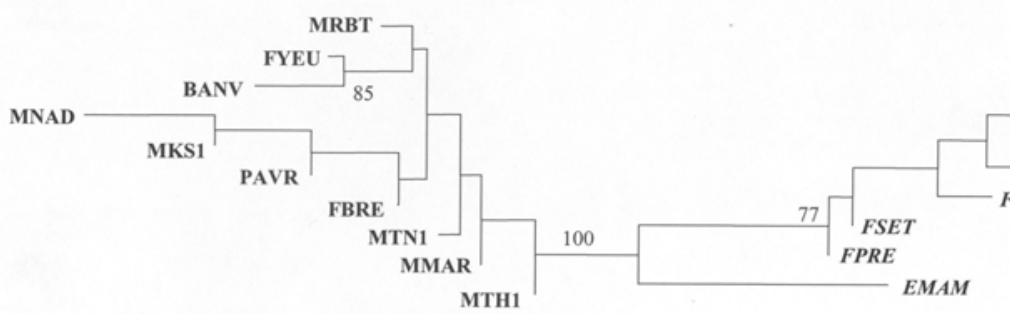

Atlantic ocean-Alboran sea

Western Mediterranean S

Fig. 3 


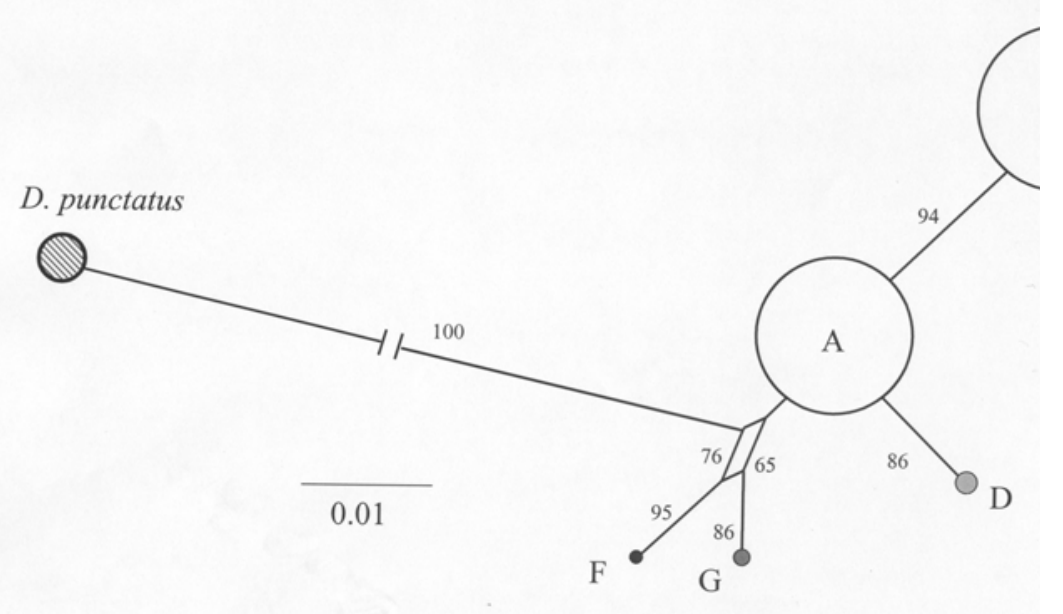

Fig. 4 
LEMAIRE ET AL

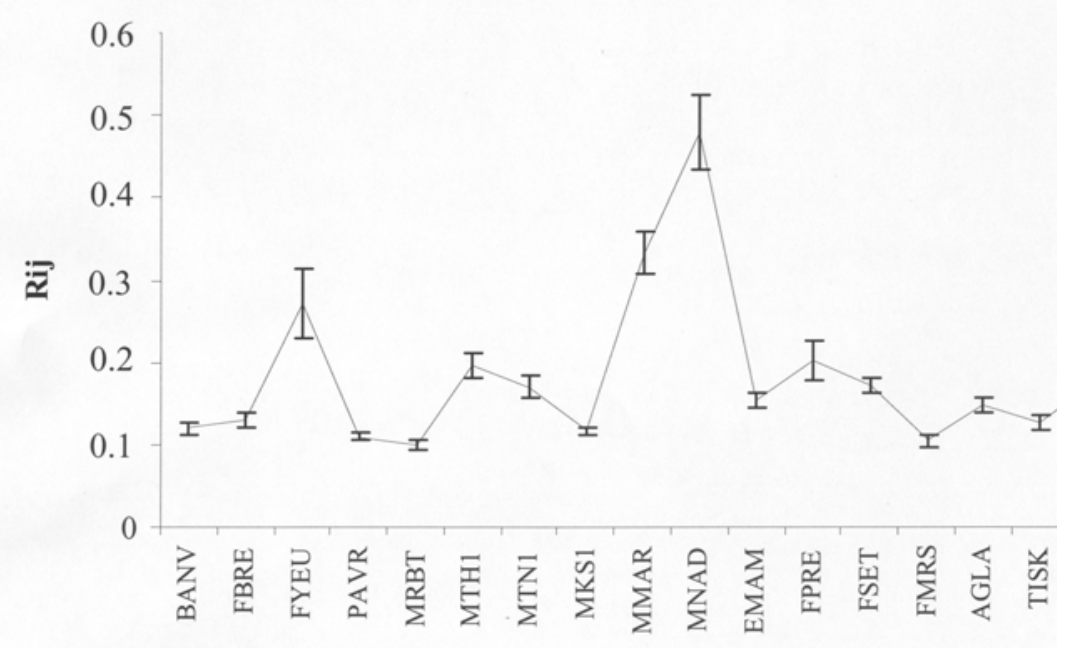

Fig. 5 